\title{
A Bacillus subtilis secreted phosphodiesterase/ alkaline phosphatase is the product of a Pho regulon gene, phoD
}

\author{
Stephen Eder, ${ }^{1}$ L. Shi, ${ }^{1}$ K. Jensen, ${ }^{2}$ K. Yamane ${ }^{3}$ and F. Marion Hulett ${ }^{1}$ \\ Author for correspondence: F. Marion Hulett. Tel: +1 312996 5460. Fax: +1 3124132691 \\ e-mail: L09495@UICVM.CC.UIC.EDU
}

\footnotetext{
1 University of Illinois at Chicago, Laboratory for Molecular Biology (M/C 567), Molecular Biology Research Facility Rm 4170, 900 South Ashland Avenue, Chicago, IL 60607, USA

2 Upjohn Corp., Kalamazoo, MI, USA

3 Institute of Biological

Sciences, Tsukuba University, Tsukuba, Ibaraki 305, Japan
}

\begin{abstract}
A secreted phosphodiesterase/alkaline phosphatase, APaseD, was purified from a culture of Bacillus subtilis JH646MS. Its phosphodiesterase activity was reminiscent of an APase isolated and characterized previously. Immunoassay and $\mathrm{N}$-terminal sequencing showed the two proteins to be identical. Using the first 20 amino acids of the mature protein, a BLAST search of GenBank was used to find an homologous sequence. An exact match was found but in a putative non-coding region. It was hypothesized that there was a base pair deletion in the phoD gene. A DNA fragment internal to the coding region was generated by PCR using template DNA from a strain which produced APaseD. The PCR fragment was cloned and used to interrupt the gene. Western blot analysis of the parent and the mutated strains showed that APaseD was missing in the mutant. Resequencing of the gene revealed a larger ORF encoding a protein similar in size to the $\mathbf{4 9} \mathrm{kDa}$ APaseD estimated by SDS-PAGE. The promoter was then cloned, sequenced and used in phoD-lacZ promoter fusions which showed that the gene was phosphate-starvation-induced and dependent on PhoP and PhoR for expression.
\end{abstract}

Keywords: Bacillus subtilis, Pho regulon, phosphodiesterase

\section{INTRODUCTION}

Nutrient depletion is a stress frequently encountered by Bacillus subtilis in its natural environment, the soil. At the end of exponential growth, when nutrients become limiting, formerly inactive genes are induced which may help with the survival response. Such responses include antibiotic production (Marahiel et al., 1987), development of competence (Albano et al., 1987; Dubnau, 1991), degradative enzyme production (Ferrari et al., 1986, 1988; Msadek et al., 1993), flagellar synthesis (Gilman \& Chamberlin, 1993), changes in respiratory/energy production pathways (Sun $e t$ al., 1996), and the formation of a dormant endospore (Burbulys et al., 1991). If the depleted nutrients are replenished before the commitment to sporulation is made then the cell may resume vegetative growth.

B. subtilis has an alkaline phosphatase (APase) gene family which is silent during vegetative growth but is turned on when phosphate starvation conditions are encountered

Abbreviation: APase, alkaline phosphatase.

The GenBank accession number for the sequence reported in this paper is U49060.
(Bookstein et al., 1990; Hulett, 1993, 1996; Hulett et al., 1990, 1991, 1994a, b). Limiting phosphate concentrations were determined to be $0.08 \mathrm{mM}$ (Hulett \& Jensen, 1988). The genes induced in response to phosphate deprivation include two regulator proteins and at least four APases. The proteins PhoP and PhoR form a two-component signal-transduction system which activates the APase genes. PhoR is a histidine kinase and PhoP is a response regulator which is phosphorylated by $\mathrm{PhoR}$ and is thought to activate the Pho regulon genes (Hulett, 1993, 1996; Hulett $e t$ al., 1994a, b). Of the APase genes studied, pho $A$ and $p h o B$ have been best characterized (Hulett $e t$ al., 1990, 1991; Bookstein et al., 1990). Together the products of these genes are responsible for $98 \%$ of the alkaline phosphatase activity during the Pho response (Hulett et al., 1994b). However, other APase proteins have been isolated and may contribute to the phosphate starvation response.

Yamane \& Maruo (1978a) isolated a protein, BC6, from the lysed cell pellet of $B$. subtilis strain 6060-BC6 (Table 1), which carries a mutation causing constitutive APase expression. A second protein, RAN1, was isolated from the culture fluid of a B. subtilis strain 6060-BC6 mutant, Ran1, which secreted APase. Antibody to RAN1 cross- 
reacted with $\mathrm{BC} 6$, showing that they were likely to be the same protein. Further experiments by Yamane \& Maruo (1978b) showed that the approximately $46 \mathrm{kDa}$ BC6 had phosphodiesterase and APase activity in a ratio of $1 \cdot 4: 1 \cdot 0$. In our efforts to study the APase gene family in $B$. subtilis we were interested in characterizing BC6 further, especially its possible relationship to the Pho regulon.

An immunoassay study suggested that BC6 was the same protein as APaseD, an APase we purified from JH646MS (Hulett et al., 1990). N-terminal sequencing of the first 20 amino acids of both proteins confirmed this. In this study we have identified the gene for APaseD and demonstrated that APaseD is a member of the Pho regulon.

\section{METHODS}

Bacterial strains and plasmids. These are listed in Table 1. Plasmids used in this study were constructed as follows.

pSE1. PCR was used to amplify the $389 \mathrm{bp}$ promoter region of phoD from JH642 template DNA. The primers used for PCR were FMH208 (TTGAATTC ${ }^{\mathbf{1 6 7 4 0}}$ GTAAGAGAACAAGAGCCTCT $^{16740}$ ) and FMH209 (TTGGATCC ${ }^{17112}$ ACGACTGTCGTATGCCATTC ${ }^{16092}$ ). The numbering on the primers is based on the numbering in the sequence submitted to GenBank with accession number D30808 (Ogawa et al., 1995). FMH208 contains an EcoRI site at its $5^{\prime}$ end and FMH209 contains a BamHI site at its $5^{\prime}$ end. The amplified DNA was then ligated to the PCRII vector provided in the TA cloning kit (Invitrogen).

pSE2. PCR was used to amplify a $292 \mathrm{bp}$ fragment from the start of the $5^{\prime}$ coding region of $p h o D$. The template DNA was from JH642. The primers used for PCR were FMH210 $\left({ }^{17077}\right.$ GAGAGAGGGGATCTTGAATG $\left.^{17101}\right)$ and FMH211 $\left({ }^{17369}\right.$ CCATTCAGCGGATCTGGTG $\left.{ }^{17350}\right)$. The amplified DNA was then ligated to the pCRII vector from Invitrogen.

pSE3. Restriction digestion of pSE1 with EcoRI and BamHI released the 389 bp promoter region. This fragment was cloned into the $B a m \mathrm{HI} / E_{c} o \mathrm{RI}$ sites of $\mathrm{pDH} 32$ to create pSE3, a pho D-lac $Z$ promoter fusion for use in lac $Z$ reporter gene assays.

pSE4. Restriction digestion of pSE2 with EcoRI released the $292 \mathrm{bp} 5^{\prime}$ coding region of $p h o D$. This fragment was cloned into the EcoRI site of pJM103 to create pSE4. pSE4 was then used to create a mutation in the APaseD gene by Campbell-type integration of the plasmid.

General methods. Transformation of E. coli was done according to the method of Hanahan (1985). Transformants were selected for drug resistance and colour on LB plates containing $150 \mu \mathrm{g}$ penicillin $\mathrm{ml}^{-1}$ and $120 \mu \mathrm{g} \mathrm{X}-\mathrm{Gal} \mathrm{m}{ }^{-1}$. Transformation of $B$. subtilis was done by the two-step transformation method of Cutting \& Vander Horn (1990). Transformants were selected for drug resistance on Tryptose Blood Agar Base (Difco) plates containing $5 \mu \mathrm{g}$ chloramphenicol $\mathrm{ml}^{-1}$.

Media, growth conditions and enzyme assays. For phosphate starvation induction of APases and the phoD promoter fusions, the cells were cultured in low-phosphate defined medium (LPDM) as described by Hulett $e$ t al. (1990). A Pase activity was determined as previously described by Hulett et al. (1990); the units are $\mu \mathrm{mol} p$-nitrophenol formed $\min ^{-1}$ at $37^{\circ} \mathrm{C}$. Specific activity was calculated by dividing the APase activity as assayed (units $\mathrm{ml}^{-\mathbf{1}}$ ) by the $\mathrm{OD}_{540}$ of the culture (determined with a Hitachi U-2000 spectrophotometer). $\beta$-Galactosidase specific activity was determined according to Ferrari et al. (1986), and was expressed in units ( $\mathrm{mg}$ protein $)^{-1}$.

Protein purification and $\mathbf{N}$-terminal sequencing. The proteins BC6 and RAN1, from the APase constitutive strain 6060-BC6, were isolated by Yamane \& Maruo (1978a). APaseD was

\section{Table 1. Bacterial strains and plasmids}

\begin{tabular}{|c|c|c|}
\hline Strain or plasmid & Genotype or antibiotic resistance & Source \\
\hline \multicolumn{3}{|l|}{ B. subtilis strains } \\
\hline $6060-B C 6$ & $\operatorname{trpB3}$ metB5 (APase constitutive) & Marburg \\
\hline JH644MS & phe $A 1$ trpC2 spo0 A12 abrB15 & J. A. Hoch \\
\hline $\mathrm{JH} 642$ & phe $A 1 \operatorname{trp} C 2$ & J. A. Hoch \\
\hline MH5117 & phe A1 trpC2 phoP $\Delta$ EcoRI mdh:: Tet ${ }^{r}$ & Hulett et al. (1994) \\
\hline MH5124 & phe $A 1$ trp C2 phoR $\Delta$ BalI:: Tet $^{\mathrm{r}}$ & Hulett et al. (1994) \\
\hline MH5441 & phe $A 1$ trpC2 amyE::phoD - lac $Z \mathrm{Cm}^{\mathrm{r}}$ & This study \\
\hline MH5442 & phe $A 1$ trpC2 phoP $\triangle$ EcoRI Tet amyE: :phoD-lac $Z \mathrm{Cm}^{\mathrm{r}}$ & This study \\
\hline MH5443 & $\begin{array}{l}\text { phe } A 1 \text { trp } C 2 \text { phoR } \Delta \text { Ball mdb:: } \mathrm{Tet}^{\mathrm{r}} \text { amyE::phoD-lacZ } \\
\mathrm{Cm}^{\mathrm{r}}\end{array}$ & This study \\
\hline MH5444 & phe A1 trpC2 phoD $\Omega$ pSE4 $\mathrm{Cm}^{r}$ & This study \\
\hline \multicolumn{3}{|l|}{ E. coli strains } \\
\hline $\mathrm{DH} 5 \alpha$ & $\begin{array}{l}\mathrm{F}^{-} \phi 80 d l a c Z \Delta M 15 \Delta(\text { lac } Z Y A-\arg F) U 169 \operatorname{rec} A 1 \text { end } A 1 \\
\text { bsdR } 17\left(\mathrm{r}_{\mathrm{k}}^{-} \mathrm{m}_{\mathrm{k}}^{+}\right) \sup E 44 \lambda^{-} \text {thi-1 gyr A relA1 }\end{array}$ & Lab. strain \\
\hline \multicolumn{3}{|c|}{ 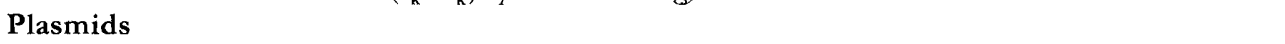 } \\
\hline pCRII $(3.9 \mathrm{~kb})$ & $A p^{r} K_{m}^{r}$ & Invitrogen \\
\hline pDH32 (9.9 kb) & $A p^{r} C^{r}$ & D. J. Henner \\
\hline pJM103 $(3.7 \mathrm{~kb})$ & $A p^{r} C^{r}$ & J. A. Hoch \\
\hline pSE1 $(4.3 \mathrm{~kb})$ & $\mathrm{Ap}^{r} \mathrm{Cm}^{r}$ & This study \\
\hline pSE2 $(4 \cdot 2 \mathrm{~kb})$ & $A p^{r} C^{r}$ & This study \\
\hline $\operatorname{pSE} 3(10 \cdot 3 \mathrm{~kb})$ & $\mathrm{Ap}^{r} \mathrm{Cm}^{\mathrm{r}}$ & This study \\
\hline $\mathrm{pSE} 4(4 \cdot 0 \mathrm{~kb})$ & $\mathrm{Ap}^{r} \mathrm{Cm}^{\mathrm{r}}$ & This study \\
\hline
\end{tabular}


isolated by the method of Hulett et al. (1990). Preparation of all three proteins for $\mathrm{N}$-terminal sequencing was done as described by Matsudaira (1987). The only differences were that the gel was $7.5 \%(\mathrm{w} / \mathrm{v})$ acrylamide and the staining was carried out for only $30 \mathrm{~s}$. Each protein was sequenced at the Harvard MicroChemistry facility on a $470 \mathrm{~A}$ protein sequencer equipped with a $120 \mathrm{~A}$ on-line PTH-AA analyser (Applied Biosystems).

Western blot analysis. MH5444, MH5117 and JH642 ('Table 1) were used to inoculate $1.5 \mathrm{ml}$ of LB medium and the cultures were incubated at $37^{\circ} \mathrm{C}$ for $3 \mathrm{~h}$. Thirty microlitres of each LB culture was then used to inoculate $1.5 \mathrm{ml}$ of LPDM. The LPDM cultures were incubated at $37^{\circ} \mathrm{C}$ with vigorous aeration for $18 \mathrm{~h}$. The amount of growth was recorded by $\mathrm{OD}_{525}$ measurement. Using the formula $\mathrm{OD}_{525} \times 83=\mu \mathrm{g}$ protein $\mathrm{ml}^{-1}$ culture, specific volumes of each sample were taken containing $50 \mu \mathrm{g}$ or $100 \mu \mathrm{g}$ of protein. The Western blot was then performed as described by Hulett $e t$ al. (1990). The primary antibody used was RAN1 anti-APase, and the secondary antibody was APaseconjugated goat anti-rabbit IgG (Bio-Rad).

Nucleotide sequencing. pSE1 and pSE2 were sequenced directly by using Sequenase and universal primers (United States Biochemical) according to the instructions of the manufacturer.

Computer searches. A BLAST search of GenBank was used to explore the B. subtilis genome for a match using the first 20 amino acids from APaseD as the search probe. The modified sequence was submitted to GenBank and has the accession number $\mathrm{U} 49060$.

\section{RESULTS}

\section{$\mathrm{N}$-terminal sequencing of BC6 and APaseD}

An immunoassay using the RAN1 anti-APase antibody (Yamane \& Maruo, 1978b) showed cross-reactivity between BC6, RAN1, and APaseD, suggesting that they are the same protein (data not shown). APaseD, RAN1 and BC6 were subjected to SDS-PAGE and blotted onto Imobilon membranes, from which the $\mathrm{N}$-terminal sequence of each protein was determined. Nineteen of the first 20 amino acids from the mature $A$ PaseD protein were found to be identical to the mature BC6 protein isolated by Yamane \& Maruo (1978a) (Fig. 1). The third amino acid in BC6 is a lysine, whereas in APaseD an asparagine was identified as the third amino acid sequenced. This asparagine/lysine discrepancy at the third amino acid can be accounted for by a single base substitution and could be due to the fact that the proteins were isolated from different strains. N-terminal sequencing of RAN1 showed that the mature RAN1 protein lacked at least five $\mathrm{N}$-terminal amino acids found in APaseD and BC6. A ragged amino terminus in a concentration ratio of $8: 4: 2: 1$ was determined for RAN1 species lacking $5,6,7$ or 8 of the $\mathrm{N}$-terminal amino acids found in APaseD and BC6 respectively.

The $\mathrm{N}$-terminal 20 amino acids of APaseD were then used to perform the BLAST sequence similarity search in the GenBank database using the program tblastn (Altschul et al., 1990). A single match with $100 \%$ identity to the search query was identified as GenBank entry D30808 and was located on the $24^{\circ}$ region of the B. subtilis chromosome (Ogawa et al., 1995). However, the DNA which would encode the amino acid sequence was within a noncoding region downstream of ORF17 and 5' of ORF18, a hypothetical gene. We hypothesized that a 1 bp deletion had disrupted the gene encoding A PaseD in the organism used for the Japanese Bacillus genome sequencing project (Ogasawara et al., 1995).

\section{Sequencing the putative APaseD ORF}

To explore the above hypothesis, we generated a PCR product from chromosomal DNA of JH642, a strain from which we had isolated APaseD. The PCR fragment included the short upstream coding region and extended $3^{\prime}$ of the sequence encoding the $\mathrm{N}$ terminus of the A PaseD protein (Fig. 1). Sequencing of the PCR product revealed an adenine missing at base pair 17207 (GenBank accession number D30808). Insertion of the deleted adenine revealed a new reading frame (Fig. 1). The newly discovered ORF connected the short upstream ORF, the DNA encoding the APaseD $N$ terminus, and the entire second ORF. The $5^{\prime}$ region of the ORF encoded 56 amino acids not found at the $\mathrm{N}$ terminus in the mature protein, suggesting that the preprotein of APaseD is a $62825 \mathrm{Da}$ protein. This peptide contained eight basic amino acids followed by a hydrophobic region and is cleaved from the preprotein after an alanine residue, which is characteristic of Gram-positive signal sequences (Von Heijne et al., 1989; Nagarajan, 1993). However, the positively charged domain is longer than in other signal peptides, making the prepeptide exceptionally long. The $56 \mathrm{kDa}$ mature protein was similar in molecular mass to that of APaseD as estimated using SDS-PAGE by Hulett (1993) (49 kDa) and Yamane \& Maruo (1978a) (46 kDa) and had an isoelectric point of $8 \cdot 6$.

In order to determine if this larger ORF actually encoded APaseD, we created a mutation in its $5^{\prime}$ coding region. The $292 \mathrm{bp}$ fragment used to sequence the $5^{\prime}$ coding region of the new ORF was ligated into the PCRII vector (Invitrogen) and then the insert was subcloned into pJM103 at its EcoRI site using the EcoRI sites flanking the insertion in the pCRII vector. The resulting plasmid, pSE4, was transformed into B. subtilis strain JH642 and chloramphenicol resistance was selected for. Due to the sequence homology between the plasmid and the phoD region of the chromosome, it was forced to integrate into the phoD locus through Campbell-type recombination, thereby creating two incomplete copies of the putative pho $D$ gene. The putative $p h o D$ mutant (MH5444), the $p h o P$ mutant (MH5117) and the parent strain (JH642) (Table 1) were then grown in low-phosphate defined medium (Hulett et al., 1990) in order to induce the expression of phoD. Fig. 2 shows the results of the Western blot performed on the crude cell lysates of these strains following phosphate starvation induction. The parent strain showed RAN1 antibody cross-reaction with protein. The $p h o D$ and phoP mutant strains did not. These results suggested two things: firstly, that the APaseD protein was encoded in the proposed reading frame; and secondly, since no protein from the phoP mutant strain cross-reacted with RAN1, that PhoP is necessary for $p h o D$ 


\begin{tabular}{|c|c|c|c|c|c|c|c|c|c|c|c|c|c|c|}
\hline \multicolumn{15}{|c|}{ EcoR I } \\
\hline GTAA & AGAACA & AGAGS & CTCCT & CTGA & AGCC & AAA & GAAG & SCTTT & $\mathrm{AGC}$ & TTGT & TTC & AT & GAT & 16817 \\
\hline AAG & GCACTO & AGTCA & ITCTGC & GAAAT & GCTC & GTGTTT & rGCT & CTTTTT & GAT & IGTGA & AGAA & AATA & ATGG & 16895 \\
\hline CGG & TTGCTT & GCAAA & GACAC & GATATC & CAGAA & AACGC & TTCATT & AGGCCA & SCTTYC & SGCATC & STTTCA & SAG & GCT & 16972 \\
\hline TGTG & GGGAAC & CGATT & TAATG & TTCAGC & GCTTAC & AATCA & STTCAC & АCTTCT & CACAC & ICGTII & $\triangle A C A A$ & RGATTTC & CTAT & 17051 \\
\hline$\frac{\mathrm{AATG}}{-10}$ & AGACGA & TCAAT & GAGAC & TGT & & & & & -35 & & -22 & & & 17076 \\
\hline RB & & & & & & & & & & Ban & $\mathrm{lHI}$ & & & \\
\hline GGA & GAG... & AGG. & GGA. & TCT. & TGA. & ATG & GCA & TAC & GAC & AGT & CGT & TTT & $\begin{array}{l}\text { GAT } \\
\text { As: }\end{array}$ & $\begin{array}{l}17118 \\
8\end{array}$ \\
\hline GAA & TGG & GTA & CAG & AAA & CTG & AAA & GAG & GAA & AGC & TTT & CAA & $\begin{array}{l}\mathrm{AAC} \\
\mathrm{A} s \mathrm{n}\end{array}$ & AAT & 17160 \\
\hline G I u & $\operatorname{Trp}$ & Val & Gln & Lys & Le u & Lys & Glu & Glu & Ser & Phe & $\mathrm{G} \mid \mathrm{n}$ & As n & As n & \\
\hline ICG & TTT & GAC & CGC & CGC & AAA & TTT & ATT & CAA & GGA & GCG & GGG & AAG & ATT & 17202 \\
\hline Th r & Phe & Asp & Arg & Arg & Lys & Phe & Ile & Gl n & Gly & $\mathbf{A} \mid \mathbf{a}$ & Gly & Lys & Ile & 36 \\
\hline GCA & $\mathrm{GGA}^{*}$ & CTT & TCT & CTT & GG & TTA & ACG & ATT & GCC & CAG & TCG & GTT & GGG & 17244 \\
\hline A la & Gly & Leu & Ser $r$ & Leu & Gly & Le u & Thr & Ile & $A \backslash \mathrm{a}$ & $G \ln$ & Ser & Val & Gly & 50 \\
\hline GCC & TTT & GAA & GTA & AAT & GCT & GCG & $\mathrm{CCT}$ & AAC & TTC & TCA & AGC & TAT & $\mathrm{CCG}$ & 17286 \\
\hline A I a & P he & Glu & Val & A s n & Ala & A l a & Pro & Asn & Phe & Set & Ser & Tyr & Pro & 64 \\
\hline TTT & $\mathrm{ACA}$ & TTA & GGG & GTA & GCG & TCA & GGT & GAT & CCG & CTT & TCT & GAC & AGT & 17328 \\
\hline Phe & Thr & Leu & Gly & $\mathrm{Val}$ & $\mathrm{A} 1 \mathrm{a}$ & $\mathrm{Se}$ & Gly & Asp & Pro & Leu & Ser & A sp & Ser & 78 \\
\hline GTC & GTG & CTT & TGG & $\mathrm{ACA}$ & CGT & CTG & GCA & $\mathrm{CCA}$ & GAT & $\mathrm{CCG}$ & CTG & AAT & GGC & 17370 \\
\hline V a l & $\mathrm{V}$ a & Leu & $\mathrm{Tr}$ & Th & A rg & Le & & Pro & As...P... & Pro & Leu & A.s.n.... & G! & 92 \\
\hline GGG & GGA & ATG & CCG & AAG & CAA & GC & GTG & $\mathrm{CCT}$ & GTC & AAA & TGG & GAG & GTC & 17412 \\
\hline Gly & Gly & Met & B. & Lys & GI & A 1 & 1 & Pro & & Lys & $\operatorname{Trp}$ & GIu & Val & 106 \\
\hline GCA & AAG & GAT & GAG & CAT & TTC & CGC & $\mathrm{AAA}$ & ATC & GT & AGA & $\mathbf{A A A}$ & GGC & $\mathrm{ACT}$ & 17454 \\
\hline A $] \mathbf{a}$ & Lys & A s p & Glu & $\mathrm{H}$ is & Phe & A I $g$ & Lys & Ile & Val & A rg & Lys & Gly & Thr & 120 \\
\hline GAA & ATG & GCT & $\mathrm{AAA}$ & $\mathrm{CCA}$ & AGT & CTT & GCC & CAT & $\mathrm{TCC}$ & GTT & $\mathrm{CAT}$ & GTG & GAA & 17496 \\
\hline G I u & Met & $A \mid \mathbf{a}$ & Lys & Pro & Ser & Le u & $A \mid a$ & $\mathrm{H}$ is & Ser & Val & $\mathrm{H}$ is & Val & Glu & 134 \\
\hline $\begin{array}{l}\mathrm{CG} \\
1 \mathrm{a}\end{array}$ & GAC & GC & $C^{-}$ & & & & & & & & & & & 17500 \\
\hline a & & & & & & & & & & & & & & \\
\hline
\end{tabular}

Fig. 1. Nucleotide sequence of the 5 region of phoD. The sequence contains the $\mathrm{N}$-terminal portion of the phoD gene and the promoter region used for the expression studies. The first 20 amino acids of the mature protein are boldly underlined. The primers used to amplify the $5^{\prime}$ coding region by PCR are underlined with dotted lines. The additional base pair (bp 17207) adenine discovered upon sequencing is typed in bold print with an asterisk. The primers used to amplify the promoter region by PCR are underlined with solid lines. Each primer contains a restriction site which is labelled above the site. Putative $-10,-22,-35$, and ribosome-binding sites (RBS) are underlined and labelled.

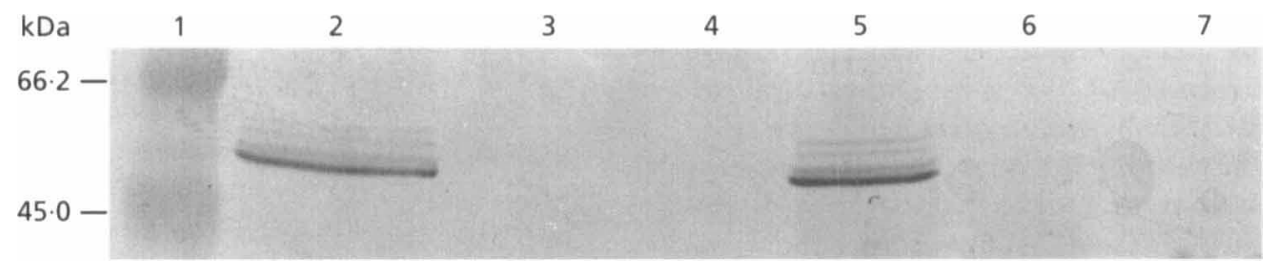

Fig. 2. Western analysis confirming the absence of $A P a s e D$ protein in a phoD mutant caused by Campbell-type integration of pSE3. Lane 1 contains protein molecular mass markers (Bio-Rad): bovine serum albumin is approximately $66.2 \mathrm{kDa}$ and ovalbumin is approximately $45.0 \mathrm{kDa}$. Lanes 2,3 and 4 contain $100 \mu \mathrm{g}$ protein from the wild-type strain (JH642), the phoP mutant strain (MH5117) and the phoD mutant strain (MH5444) respectively. Lanes 5, 6 and 7 contain $50 \mu \mathrm{g}$ of protein from $\mathrm{JH} 642, \mathrm{MH} 5117$ and $\mathrm{MH} 5444$, respectively.

activation. Cells from each culture used for the Western blot were also assayed for APase specific activity according to Jensen et al. (1993) in order to determine how a phoD null mutation would affect total APase levels during the phosphate starvation response. JH642 (wild- type) and MH5444 (phoD) produced similar APase specific activities while $\mathrm{MH} 5117(p h o P)$ showed $5 \%$ of wild-type levels (data not shown). This confirmed that APaseD is not a major contributor to total APase, at least under these culture conditions in the JH642 background. 


$\begin{array}{ll}\text { Gene } & \text { Product } \\ \text { phoA } & \text { APaseA } \\ \text { phoB } & \text { APaseB } \\ \text { phoD } & \text { APaseD } \\ \text { tuaA } & \begin{array}{l}\text { Teichuronic acid } \\ \text { biosynthesis }\end{array}\end{array}$

Promoter region
-22
TTAACAAAGTTTCCCTAACAT
TTAACAGTTTAAAAATATAAT
TTAACAATGATTTCC
TTATAAT
TTAACATCCGTCTGC $\underline{\text { TAAACT }}$

Fig. 3. Promoters of a number of Pho regulon genes have several common features. The -10 region has a consensus similar to sigma A promoters. There is either a poorly conserved sigma $A$ sequence at -35 or none at all. However, $9 \mathrm{bp}$ upstream of the -10 region $(-22)$ there is a conserved TTAACA as shown here.

\section{APaseD is Pho regulated}

In order to confirm that APaseD expression is Pho regulated, we amplified by PCR a 398 bp fragment which contained the promoter region of $p h o D$. This fragment was then cloned ( $\mathrm{pSE} 1$ ), sequenced and used to make phoD-lac $Z$ promoter fusions for expression studies. The sequence agreed with the NCBI database, which showed that $9 \mathrm{bp}$ upstream of the putative -10 (TATAAT) was the sequence TTAACA which has been observed in the promoter regions of $p h o A, p h o B$ and tua $A$ (Hulett et al., 1994a), all of which have been characterized as Phoregulated genes (Fig. 3). phoD promoter expression studies were then undertaken in order to conclusively determine whether PhoP controls phoD. For this purpose the promoter fragment was subcloned from pSE1 into the integration vector $\mathrm{pDH} 32$. The resulting plasmid, $\mathrm{pSE} 3$, was linearized at the Pst I site and used to transform the wild-type B. subtilis strain (JH642), the phoP mutant strain (MH5117) and the phoR mutant strain (MH5124), (Table 1). A single copy of the linearized DNA was integrated into the chromosomes at the amyE locus. The transformants were selected for chloramphenicol resistance and screened for the loss of $\alpha$-amylase synthesis on starch plates. Each strain was then grown in low-phosphate defined medium (Hulett et al., 1990), which is designed to maximize vegetative APase production in $B$. subtilis. Samples were taken every hour for $12 \mathrm{~h}$ and assayed for APase and $\beta$-galactosidase activity. Fig. 4 shows the results of these assays. Neither enzyme was expressed in any strain during the first $6 \mathrm{~h}$ while phosphate concentrations were above $0.1 \mathrm{mM}$. MH5441, the wild-type strain with the phoD-lac $Z$ fusion, did show some $\beta$ galactosidase and APase activity initially because the cells had been grown overnight under phosphate-limiting conditions before being transferred to fresh LPDM at the beginning of the assays. During exponential growth the specific activity of these enzymes decreased as culture density increased, without additional enzyme synthesis. When the strains entered the stationary phase because of phosphate depletion, only the wild-type strain, MH5441, produced $\beta$-galactosidase and APases. Neither the $p h o P$ mutant strain (MH5442) nor the phoR mutant strain (MH5443) expressed activity. From these data we conclude that the $p h o D$ gene is Pho regulated, requiring both PhoP and PhoR for its induction.

\section{DISCUSSION}

The natural depletion of nutrients from the soil leads to the activation of $B$. subtilis genes directed at overcoming the deficiency (Msadek et al., 1993). Phosphate limitation leads to the activation of Pho regulon genes (Hulett, 1993, 1996; Hulett et al., 1990, 1991, 1994a, b; Bookstein et al., 1990). APaseA and APaseB are the two major Phoregulated alkaline phosphatases produced under these conditions, and together they account for $98 \%$ of the
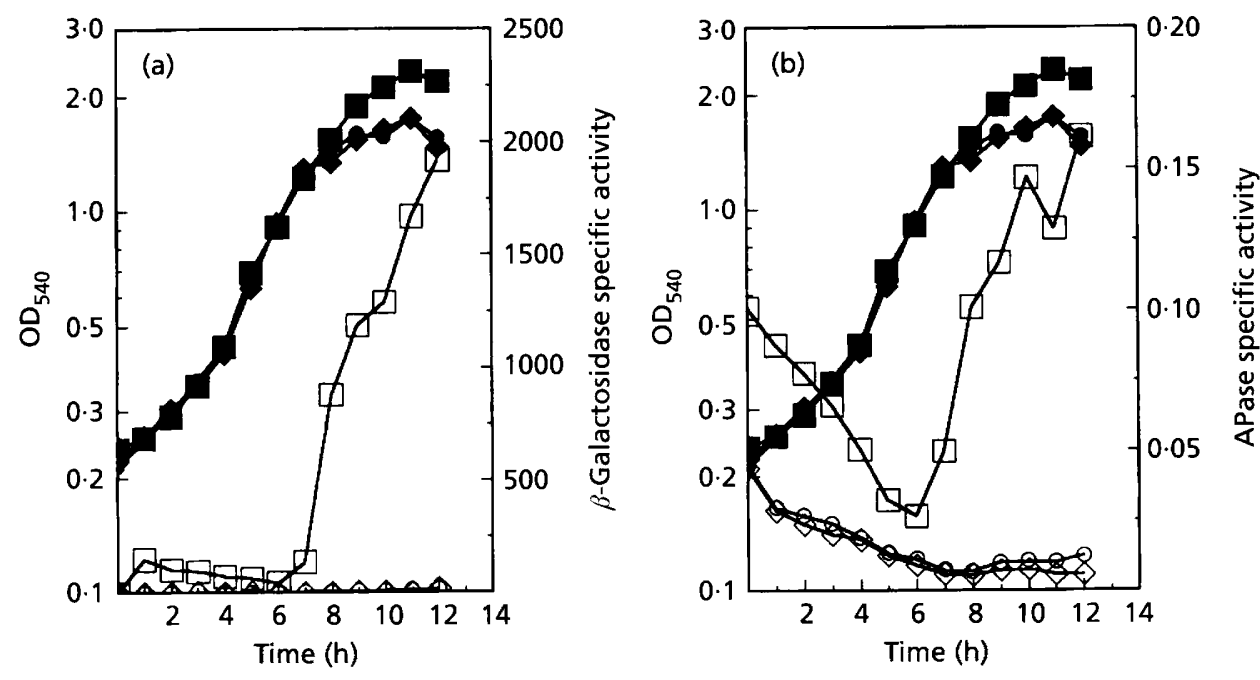

Fig. 4. The phoD promoter is phosphate starvation induced. Strains were grown in LPDM according to Hulett et al. (1990). Growth is represented by the filled symbols in (a) and (b). (a) $\beta$-Galactosidase specific activity [units (mg protein) ${ }^{-1}$ ] is represented by the open symbols. (b) APase specific activity (units $\mathrm{ml}^{-1}$ per $O D_{540}$ unit) is represented by the open symbols. The strains are: $\square$, MH5444 (amyE::phoD-lacZ); $\diamond, \diamond$, MH5442 (phoP $\triangle$, amyE::phoD-lacZ); and $\bullet, O$, MH5443 (phoRA, amyE::phoD-lacZ). 
alkaline phosphatase specific activity expressed (Hulett et al., 1994b). However, APases other than APaseA and $A P a s e B$ are also induced during the phosphate starvation response and their role must not be discounted. Yamane \& Maruo (1978a) had previously isolated two proteins, BC6 and RAN1, which had both APase and phosphodiesterase activity. Antibody was made against RAN1 and an immunoassay of RAN1 and BC6 showed crossreactivity, which suggested that the two isolated proteins were the same although RAN1 was secreted and BC6 was cell bound.

$\mathrm{N}$-terminal sequencing of APaseD, RAN1 and BC6 revealed that they were in fact the same protein. Further analysis showed a single amino acid difference (asparagine to lysine) among the first 20 amino acids of APaseD and BC6, which could result from a strain difference affecting a single base pair. Sequence analysis of the secreted protein, $\mathrm{RAN1}$, revealed a ragged $\mathrm{N}$ terminus, indicating that the protein preparation analysed contained protein species lacking between five and eight amino acids found at the $\mathrm{N}$ terminus of mature APaseD or BC6. These data suggest the mutation in the B. subtilis RAN1 strain results in proteolysis of APaseD that allows secretion of the protein into the medium. Although these data reveal no information concerning the mechanism for the cell association of APaseD or BC6, they do imply that one or more of the five $\mathrm{N}$-terminal amino acids of the mature APaseD is required for cell association.

The N-terminal sequences allowed us to identify the gene encoding APaseD. DNA $5^{\prime}$ of the coding region for the mature enzyme indicated that APaseD is translated as a preprotein having 56 additional amino acids which share certain characteristics of secretory signal peptides. The uncharged residues in position -3 and -1 relative to the cleavage site and the central hydrophobic region are typical of other signal peptides (Von Heijne \& Abrahmsen, 1989; Nagarajan, 1993) but the charged $\mathrm{N}$ terminus is exceptionally long and highly charged. This $\mathrm{N}$-terminal domain is longer than most complete signal sequences, which are about 35 amino acids long. This raises the question of whether the translocation and maturation of APaseD might not involve a novel process. Certainly, whole cell lysates of phosphate-starved cells contain several cross-reacting proteins of discrete sizes. This is reminiscent of the multiple processed lengths of Bacillus licheniformis $749 \mathrm{C}$ penicillinase (Lampen et al., 1984 ) and the subtilisin pre-pro-protein maturation (Vasantha et al., 1984). It leads us to believe that these cross-reacting proteins are processed forms of APaseD; this hypothesis is supported by the fact that the crossreacting species are all absent in the phoD mutant.

Two lines of evidence suggested that $p h o D$ was a Pho regulon gene. First, we isolated it from phosphate-starved cells. Second, we noted that the promoter region contained a conserved 6 bp sequence (TTAACA), located 9 bp $5^{\prime}$ of a putative -10 consensus (TATAAT) that is found in the promoters of three Pho regulon genes, pho $A$, pho $B$ and tua $A$. Assignment of phoD to the growing list of Pho regulon genes is justified based on: (1) the induction of gene expression during phosphate starvation of the culture; (2) the absence of APaseD protein in a phoP mutant; and (3) the absence of transcription of $p b o D$ in either a $p b o P$ or a $p b o R$ mutant.

The amino acid sequence of APaseD showed no similarity to any protein in the databases available and is quite different from that of other APases. APases previously cloned and sequenced are conserved in their active site and core structure (Hulett et al., 1991). APaseD is a basic protein, as are APase $A$ and $A$ PaseB of B. subtilis, but there is no cross-reaction between $\mathrm{APase} A$ and $\mathrm{APaseB}$ with the RAN1 antibody using the purified protein (unpublished data) or crude whole-cell lysates of phoD mutants which contain APaseA and APaseB (Fig. 2). Also, antibodies to APase A or APaseB do not cross-react with APaseD (unpublished data).

The role of APaseD in the Pho response may now be explored using the phoD mutant. Earlier data (Yamane \& Maruo, 1978a) and data presented here suggest that APaseD is a secreted but cell-associated protein that has phosphodiesterase and APase activity. We propose that the positively charged APaseD may be associated with the negatively charged cell wall. In this negatively charged wall there are anionic polymers, teichoic acids, which contain many phosphodiester bonds (Archibald et al., 1993). When B. subtilis is grown in low-phosphate media teichoic acids are replaced by teichuronic acids, which do not contain phosphate (Grant, 1979; Mauël et al., 1991). Teichuronic acid synthesis is Pho regulated (Soldo et al., 1995). Thus, we hypothesize that the Pho-reguloninduced APaseD may function to cleave the phosphodiester bonds of teichoic acids while teichuronic acid biosynthesis genes are induced to replace the teichoic acid polymers with teichuronic acids. The product of the diesterase reaction may provide the substrate for a phosphomonoesterase (APaseD, APaseA or APaseB) resulting in the release of inorganic phosphate for cell growth. However, it is likely to be more complicated since just as there are multiple phosphomonoesterases in $B$. subtilis, there are surely multiple secreted proteins with diesterase activity (Le Hegarat \& Anagnostopoulos, 1973) and more specifically with teichoicase activity (Kusser \& Fiedler, 1982, 1983).

\section{ACKNOWLEDGEMENTS}

We thank Stephanie Birkey, Mary Fran Duggan and Beth Feeney for helpful comments concerning the preparation of the manuscript.

This work was supported by Public Health Service research grant GM33471 from the National Institutes of Health.

\section{REFERENCES}

Albano, M., Hahn, J. \& Dubnau, D. (1987). Expression of competence genes in Bacillus subtilis. J Bacteriol 169, 3110-3117.

Altschul, S. F., Gish, W., Miller, W., Myers, E. W. \& Lipman, D. J. (1990). Basic local alignment search tool. J Mol Biol 215, 403-410. Archibald, A. R., Hancock, I. C. \& Harwood, C. R. (1993). Cell wall structure, synthesis, and turnover. In Bacillus subtilis and Otber Gram-positive Bacteria: Biochemistry, Physiology and Molecular Genetics, pp. 381-410. Edited by A. L. Sonenshein, J. A. Hoch \& R. Losick. Washington, DC: American Society for Microbiology. 
Bookstein, C., Edwards, C. W., Kapp, N. V. \& Hulett, F. M. (1990). The Bacillus subtilis 168 alkaline phosphatase III gene; impact of a pho AIII mutation on total alkaline phosphatase synthesis. J Bacteriol 172, 3730-3737.

Burbulys, D., Trach, K. A. \& Hoch, J. A. (1991). Initiation of sporulation in B. subtilis is controlled by a multicomponent phosphorelay. Cell 64, 545-552.

Cutting, S. M. \& Vander Horn, P. B. (1990). Genetic analysis. In Molecular Biological Methods for Bacillus, pp. 27-74. Edited by C. R. Harwood \& S. M. Cutting. New York: John Wiley.

Dubnau, D. (1991). Genetic competence in Bacillus subtilis. Microbiol Rev 55, 395-424.

Ferrari, E., Howard, S. \& Hoch, J. A. (1986). Effect of stage 0 sporulation mutants on subtilisin expression. I Bacteriol 166, 173-179.

Ferrari, E., Henner, D., Perego, M. \& Hoch, J. A. (1988). Transcription of Bacillus subtilis subtilisin and expression of subtilisin in sporulation mutants. J Bacteriol 170, 289-295.

Gilman, M. \& Chamberlin, M. (1993). Developmental and genetic regulation of Bacillus subtilis genes transcribed by sigma-28 RNA containing polymerase. Cell 35, 285-293.

Grant, W. D. (1979). Cell wall teichoic acid as a reserve phosphate source in Bacillus subtilis. J Bacteriol 137, 35-43.

Hanahan, D. (1985). Techniques for transformation of E. coli. In DN.A Cloning II: A Practical Approach, pp. 109-135. Edited by D. M. Glover. Washington, DC: IRL Press.

Hulett, F. M. (1993). Regulation of phosphorus metabolism. In Bacillus subtilis and Other Gram-positive Bacteria: Biachemistry, Physiology, and Molecular Genetics, pp. 229-235. Edited by A. L. Sonenshein, J. A. Hoch \& R. Losick. Washington, DC: American Society for Microbiology.

Hulett, F. M. (1996). The signal transduction network for Pho regulation in Bacillus subtilis. Mol Microbiol 19, 933-939.

Hulett, F. M. \& Jensen, K. (1988). Critical roles of spo0A and spo0H in vegetative alkaline phosphatase production in Bacillus subtilis. J Bacteriol 170, 3765-3768.

Hulett, F. M., Bookstein, C. \& Jensen, K. (1990). Evidence for two structural genes for alkaline phosphatase in Bacillus subtilis. J Bacteriol 172, 735-740.

Hulett, F. M., Kim, E. E., Bookstein, C., Kapp, N. V., Edwards, C. W. \& Wyckoff, H. W. (1991). Bacillus subtilis alkaline phosphatases III and IV. Cloning, sequencing, and comparisons of deduced amino acid sequence with Escherichia coli alkaline phosphatase threedimensional structure. J Biol Chem 226, 1077-1084.

Hulett, F. M., Sun, G. \& Liu, W. (1994a). The Pho regulon of Bacillus subtilis is regulated by sequential action of two genetic switches. In Phosphate in Microorganisms: Cellular and Molecular Biology, pp. 50-54. Edited by A. Torriani-Gorini, E. Yagil \& S. Silver. Washington, DC: American Society for Microbiology.

Hulett, F. M., Lee, J., Shi, L., Sun, G., Chesnut, R., Sharkova, E., Duggan, M. F. \& Kapp, N. (1994b). Sequential action of twocomponent genetic switches regulates the Pho regulon in Bacillus subtilis. J Bacteriol 176, 1348-1358.

Jensen, K. K., Sharkova, E., Duggan, M. F., Qi, Y., Koide, A., Hoch, J. A. \& Hulett, F. M. (1993). Bacillus subtilis transcription regulator, Spo0A, decreases alkaline phosphatase levels induced by phosphate starvation. J Bacteriol 175, 3749-3756.

Kusser, W. \& Fiedler, F. (1982). Purification, $M_{\mathrm{r}}$-value and subunit structure of a teichoic acid hydrolase from Bacillus subtilis. FEBS Lett 149, 67-70.
Kusser, W. \& Fiedler, F. (1983). Teichoicase from Bacillus subtilis Marburg. J Bacteriol 155, 302-310.

Lampen, J. O., Wang, W., Mezes, P. S. F. \& Yang, Y. Q. (1984). $\beta$ Lactamases of bacilli: nature and processing. In Genetics and Biotechnology of Bacilli, pp. 129-140. Edited by A. T. Ganesan \& J. A. Hoch. New York: Academic Press.

Le Hegarat, J. C. \& Anagnostopoulos, C. (1973). Purification, subunit structure and properties of two repressible phosphohydrolases of Bacillus subtilis. Eur J Biochem 39, 525-539.

Mauël, C., Young, M. \& Karamata, D. (1991). Genes concerned with synthesis of poly(glycerol phosphate), the essential teichoic acid in Bacillus subtilis strain 168, are organized in two divergent transcription units. J Gen Micrabiol 137, 929-941.

Marahiel, M. A., Zuber, P., Czekay, G. \& Losick, R. (1987). Identification of the promoter for a peptide antibiotic biosynthesis gene from Bacillus brevis and its regulation in Bacillus subtilis. J Bacteriol 169, 2215- 2222.

Matsudaira, P. (1987). Sequence from picomole quantities of proteins electroblotted onto poly vinylidene difluoride membranes. J Biol Chem 262, 10035-10038.

Msadek, T., Kunst, F. \& Rapoport, G. (1993). Two-component regulatory systems. In Bacillus subtilis and Other Gram-positive Bacteria: Biochemistry, Physiology, and Molecular Genetics, pp. 729-745. Edited by A. L. Sonenshein, J. A. Hoch \& R. Losick. Washington, DC: American Society for Microbiology.

Nagarajan, V. (1993). Protein secretion. In Bacillus subtilis and Other Gram-positive Bacteria: Biochemistry, Physiology, and Molecular Genetics, pp. 713-726. Edited by A. L. Sonenshein, J. A. Hoch \& R. Losick. Washington, DC: American Society for Microbiology.

Ogasawara, N., Fujita, Y., Kobayashi, Y., Sadaie, Y., Tanaka, T., Takahashi, H. \& Yamane, K. (1995). Systematic sequencing of the Bacillus subtilis genome: progress report of the Japanese group. Microbiology 141, 257-259.

Ogawa, K., Akagawa, E., Nakamura, K. \& Yamane, K. (1995). Determination of a 21548 bp nucleotide sequence around the $24^{\circ}$ region of the Bacillus subtilis chromosome. Microbiology 141, 269-275.

Soldo, B., Lazarevic, V., Pagni, M., Mauël, C. \& Karamata, D. (1995). The 8th international conference on Bacilli. p. 77.

Sun, G., Sharkova, E., Chesnut, R., Birkey, S., Duggan, M. F., Sorokin, A., Pujic, P., Ehrlich, S. D. \& Hulett, F. M. (1996). Regulators of aerobic and anaerobic respiration in Bacillus subtilis. J Bacteriol 178, 1374-1385.

Vasantha, N., Thompson, L. D., Rhodes, C., Banner, C., Nagle, J. \& Filpula, D. (1984). Genes for alkaline protease and neutral protease from Bacillus amyloliquefaciens contain a large open reading frame between the regions coding for signal sequences and mature protein. J Bacteriol 159, 811-819.

Von Heijne, G. \& Abrahmsen, L. (1989). Species-specific variation in signal peptide design. FEBS Lett 244, 439-446.

Yamane, K. \& Maruo, B. (1978a). Purification and characterization of extracellular soluble and membrane-bound insoluble alkaline phosphatases possessing phosphodiesterase activities in Bacillus subtilis. J Bacteriol 134, 100-107.

Yamane, K. \& Maruo, B. (1978b). Alkaline phosphatase possessing alkaline phosphodiesterase activity and other phosphodiesterases in Bacillus subtilis. J Bacteriol 134, 108-114.

Received 14 November 1995; revised 19 February 1996; accepted 5 March 1996. 